\title{
LADM-Based Model for Natural Resource Administration in China
}

\author{
Zhongguo $\mathrm{Xu}^{1,2}$, Yuefei Zhuo ${ }^{1,2}{ }^{\mathbb{D}}$, Rong Liao ${ }^{1,3}$, Cifang $\mathrm{Wu}^{1,2}$, Yuzhe $\mathrm{Wu}^{1,2}$ and Guan $\mathrm{Li}^{2,4, * \mathbb{C}}$ \\ 1 Department of Land Administration, School of Public Affairs, Zhejiang University, 866 Yuhangtang Road, \\ Hangzhou 310058, China; mailxzg@zju.edu.cn (Z.X.); zhuo27586@alumni.itc.nl (Y.Z.); \\ rosyliao@zju.edu.cn (R.L.); wucifang@zju.edu.cn (C.W.); wuyuzhe@zju.edu.cn (Y.W.) \\ 2 Land Academy for National Development, Zhejiang University, Hangzhou 310029, China \\ 3 Department of Foreign Affairs, China Land Surveying and Planning Institute, No.37 West Guanyingyuan \\ District, Beijing 100035, China \\ 4 Law School, Ningbo University, Ningbo 315211, China \\ * Correspondence: liguan1688@zju.edu.cn
}

Received: 23 August 2019; Accepted: 10 October 2019; Published: 14 October 2019

\begin{abstract}
China's rapid urbanization and industrialization have continually placed massive pressure on the country's natural resources. The fragmented departmental administration of natural resources also intensifies the problem of sustainable use. Accordingly, China's central government has launched natural resource administration reform from decentralization to unification. This study systematically analyzes the reform requirements from legal, organizational, and technical aspects. The right structure of China's natural resource assets for fulfilling such requirements is examined in this work through a review of relevant legal text, and such a right structure is converted into a draft national technical standard of China's natural resource administration on the basis of the land administration domain model (LADM). Results show that China's natural resource administration covers lands, buildings, structures, forests, grasslands, waters, beaches, sea areas, minerals, and other fields. The types of private rights over natural resources include ownerships, land-contracted management rights (cultivated land, forest land, grassland, and water area), rights to use construction land (state-owned and collective-owned), rights to use agricultural land, rights to use homestead land, breeding rights on water areas and beaches, rights to use sea areas, rights to use uninhabited islands, and mining rights. The types of public rights over natural resources include comprehensive land use, urban and rural, sea use, and territory space planning. Furthermore, various types of these property rights can be converted into corresponding classes in LADM on the basis of the analysis of the property subject, object, and rights.
\end{abstract}

Keywords: natural resources; land administration domain model; cadastre; real estate registration; China

\section{Introduction}

Since China's reform and opening up, the country has entered a long period of rapid urbanization and industrialization. As a result, such rapid geographical processes continue to place massive pressure on natural resources [1]. China's frequent natural disasters in recent years, such as floods, sandstorms, smog, and red tides, are warning signs of the overload on and insufficient protection of natural resources [2,3]. To promote the sustainable use of natural resources, China's central government has accelerated ecological civilization development and proposed centralized and unified reform measures for the natural resource assets and territory space planning on the basis of systematic ecological ideas to improve the community of "mountains, rivers, forests, farms, lakes, and grasses". From being 
scattered among various ministries, the administrative functions of natural resource assets and space use control are now integrated into the newly established Ministry of Natural Resources under the Central Government Organization Reform of 2019. China's central government is attempting to change severe situations as soon as possible through legal, organizational, and technical reform from decentralization to unification.

Appropriate natural resource administration is the key to sustainable development $[4,5]$. Property right registration of land and other natural resources is the foundation of natural resource administration [6,7]. However, space use regulation plays a vital role in alleviating the pressure on resources and the environment and promoting sustainable development after industrial civilization [4]. Modern natural resource administration consists of property tenure, use, and value management [8]. Supporting the implementation of law, organization, and technology contributes to achieving effective results $[4,7]$. The land administration domain model (LADM) is a standardized technical support system proposed by the international land management science community to meet the requirements of law and organizational administration and achieve sustainable utilization of land and other related natural resources [9-11]. After the model's proposal, its effectiveness has been repeatedly demonstrated by the International Federation of Surveyors (FIG), International Organization for Standardization (ISO), and other international organizations, and the model has become an international standard [12-14]. Moreover, LADM has been widely utilized worldwide and achieved fruitful results [15]. The application of LADM is not limited to land; it covers many domains, such as sea [16,17], housing [18], cultural heritage $[19,20]$, and municipal facilities [21,22]. It is notable that the international academic community approved and issued the Open Geospatial Consortium (OGC) Land and Infrastructure Conceptual Model Standard (LandInfra) in 2016 [23] and the OGC InfraGML 1.0-LandInfra Encoding Standards (Parts 0-7) in 2017 [24]. These standards comprise parts on Land Division and Condominium and absorb the design conceptions of LADM into organizing land and facilities information management, which can be regarded as an application or extension of LADM. Presently, FIG has provided a new working item proposal to ISO. It can be said that, therefore, LADM has officially entered the revision process of the second edition. The proposal covers some core modules such as land evaluation and taxation, spatial planning, transaction process, 3D cadastre, etc. [25,26].

To meet the reform requirements of China's natural resource (real estate) administration system, Chinese scholars have conducted pilot studies in China by using the LADM standard. Zhuo et al. took the lead in proposing China's LADM that integrates land and housing administration on the basis of organizing the legal documents and technical standards of land and housing administration [27]. $\mathrm{Yu}$ et al. and Shen et al. proposed the China real estate registration domain model by organizing the legal text and technical specifications of the unified registration of real estate [28,29]. Guo et al. designed an LADM-based model suitable for China's 3D cadastral administration to meet the needs of 3D land utilization in densely populated areas [30]. These studies have provided important academic contributions to improving the technical management of China's natural resources. However, two research deficiencies remain. First, the response to the demand for natural resource reform in China is insufficient. This observation is highlighted in the inadequate response to the legal reform of natural resource administration in rural areas. Second, the response to the reform of unified control of space utilization is inadequate. This situation is highlighted in the inadequate response to the legal reform of public rights over natural resources. This study attempts to address these deficiencies.

The motivation of this study is to respond to the reform demands for China's natural resource assets and territory space planning and propose solutions to improve the technical management of natural resources in accordance with the legal and organizational reform of natural resources. The research problem in this article is to conceive a draft technical standard of natural resource administration that meets the requirements of the LADM standard and the needs of China's natural resource administration. The scope of the natural resource administration objects involved in this study is limited to that covered by "the provisional regulations on real estate registration" and "the measures for uniform adjudication and registration of natural resources". Moreover, this work is 
limited to discussing the static model of natural resource administration. This study contributes to (1) systematically organizing the rights structure of China's natural resource assets and (2) proposing a draft national standard for natural resource administration that is suitable for China's national conditions in accordance with the requirements of the international standard. The framework of China's natural resource administration reform is newly developed, and a technical framework for adapting to the new legal system and organizational structure remains unavailable. This research contributes to the proposal of a national technical standard to improve the administration of natural resources.

\section{Methodology}

A structured computer information system development method is used in this work (Figure 1) [31,32]. First, a scientific literature review is performed to identify the research problem. Second, the development requirements of the information system are determined through policy text analysis and retrieval of relevant laws and standards. Third, a property right model is developed by analyzing relevant legal text. Fourth, a domain model is proposed using an object-oriented design based on the unified modeling language (UML). Lastly, the results and insufficiencies of the studied research are summarized through a discussion of the responsiveness to the research problem and reform requirements. In line with these research steps, the article is structured as follows. The first section introduces the research background, motivation, and question. The second section presents the roadmap of the research and the research method used for each part. The third section outlines the reform requirements for China's natural resource assets and territory space planning and further organizes the reform content from legal, organizational, and technical aspects. The fourth section discusses the property right model of "subject-rights-object" item by item by summarizing relevant laws and regulations. The fifth section converts the property right model into a domain one through an object-oriented design method based on UML and further conceives a technical standard draft for China to meet the requirements of the LADM technical standard and the standard of the real estate registration database. The final section presents the research results and summarizes the overall findings as responses to the research question and reform requirements.

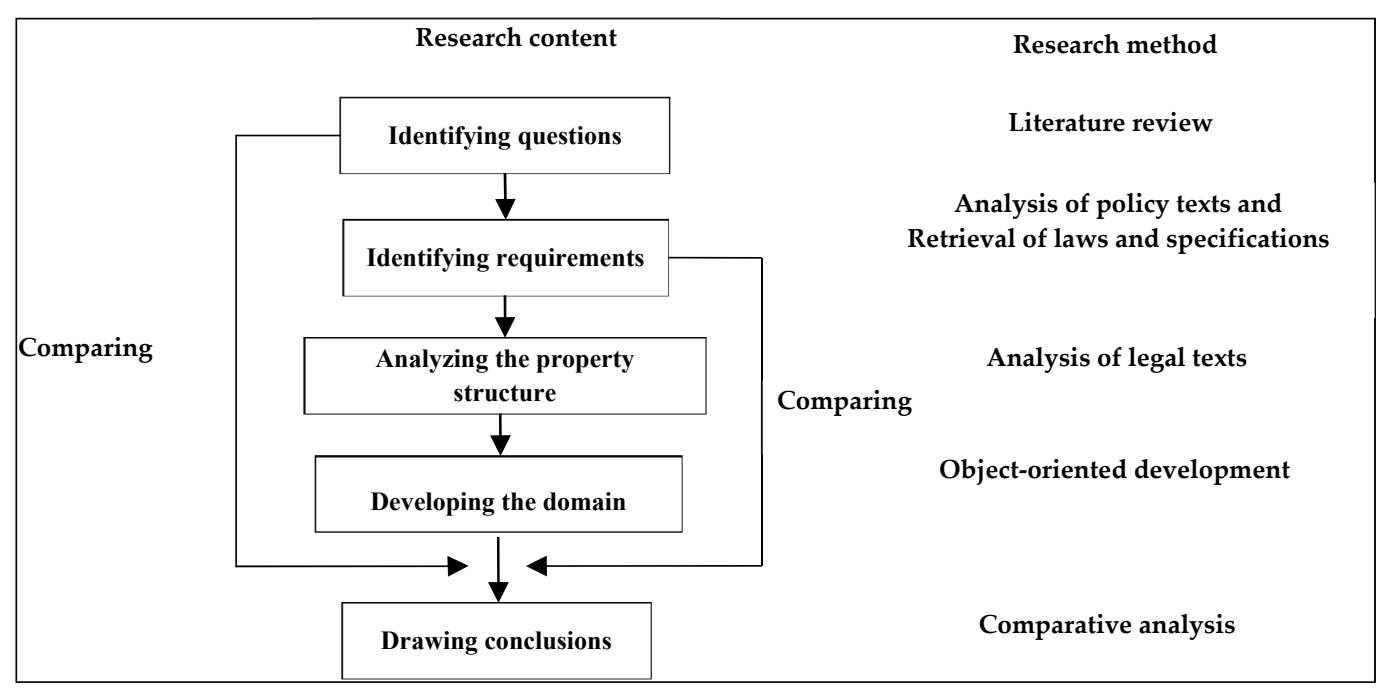

Figure 1. Research roadmap of China's natural resource administration domain model.

\section{China's Natural Resource Administration}

This article adopts Zevenbergen's method of systematic analysis in land registration domain. Each analysis step is considered as a process or procedure whose function is to convert inputs into outputs through a scientific method [7]. Figure 2 shows the inputs and output of the analysis process of identifying related requirements. This section presents the reform requirements of natural resource 
administration obtained through structural policy text analysis method, that is, an analysis of the documents issued by China's central government (see footnote 1) and a systematic retrieval and review of relevant legal provisions and technical specifications (see Appendix A Tables A1 and A2).

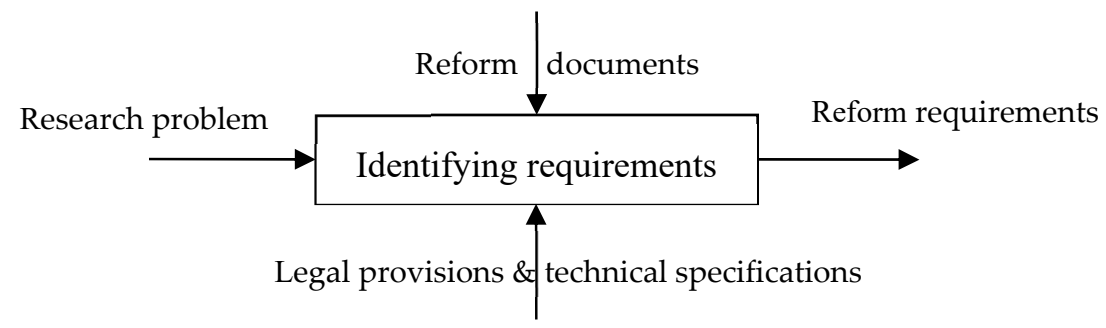

Figure 2. Inputs and output of the analysis process of identifying related requirements.

\subsection{Requirements for Natural Resource Administration Reform}

For a long time, China's natural resource administration system was characterized by a divide-and-conquer strategy. Systematic natural resources were divided into different categories, such as lands, minerals, and forests, and administrated by different ministries correspondingly. Legislatures enacted administrative laws according to the type of natural resources. Administrative organs established competent departments, and competent authorities performed administration in accordance with relevant legal provisions. The decentralized governance solved several problems in relation to natural resources, but the central government lacked a coordination mechanism and means. Consequently, ministries managed their own affairs in isolation, the administrative regulations and technical specifications they issued were in conflict, and sustainable use of resources remained a serious problem. To this end, the central government issued policy documents, such as "opinions on accelerating the construction of ecological civilization," which aim to transform the decentralized system into a unified one. Such opinions propose unified reform measures from three aspects, namely, legal improvement, organizational restructuring, and technical integration.

\subsection{Legal Aspect}

China's legal system for natural resource administration is typically hierarchical (see Table A1 in the Appendix A). A higher law has a higher legal effect than a lower one. The highest-ranking law is the constitution, which is enacted by the National People's Congress (NPC). The constitution is the fundamental law of the nation and stipulates the rights over natural resources, such as ownership and use rights. The second level of the laws is the comprehensive or separate laws promulgated by NPC or the standing committee of NPC. The third level of laws is the administrative legal rules promulgated by the state council, and these are generally the implementation rules of the upper-level law or the administrative provisions authorized by such a law. The fourth level of laws is the legal rules formulated by ministries and commissions directly under the state council or by the people's congresses of provinces and municipalities directly under the central government and their standing committee. The fifth level of laws is the normative documents formulated by national ministries or provincial governments. The general direction of the legal reform of natural resource administration is to strengthen the unified legislation of natural resource assets and territory space use. Notably, the provisions on property rights over natural resources should be stipulated uniformly in the property law. Meanwhile, administrative provisions on space use regulation should be uniformly stipulated in the law of territory space planning.

\subsection{Organizational Aspect}

In 2019, the central committee of CPC and the state council decided to rearrange the organizational structure of ministries and commissions under the state council. The newly established Ministry of Natural Resources undertakes the personnel and responsibilities of many former ministries and 
commissions under the state council. The ministries involved include the former Ministry of Land and Resources, the State Bureau of Forests, the State Bureau of the Sea, the State Bureau of Surveying and Mapping, the Development and Reform Commission, the Ministry of Housing and Construction, the Ministry of Water Resources, and the Ministry of Agriculture. In the Ministry of Natural Resources, the corresponding departments or bureaus are responsible for the affairs of natural resources. Generally, they can be divided into two categories. The first one is comprehensive administration organization. The scattered registration functions of natural resource assets are integrated into a unified regulatory authority that is responsible for the adjudication and registration of rights. Similarly, the management functions of major spatial plans, such as land use planning, urban and rural planning, and sea use planning, are integrated into the newly established institution, which is responsible for unified space use regulation affairs. The second category is specific administration organization. The corresponding departments and bureaus of land, forest, grassland, minerals, and ocean are established according to their respective legal authorization to implement administrative approval for the development and utilization of various natural resources.

\subsection{Technical Aspect}

After the promulgation of the Property Law in 2007, various ministries in charge of natural resources issued corresponding technical specifications in accordance with the requirements of the Property Law to adjudicate and register the rights over natural resource assets in their charge (Table A2 in the Appendix A). Each competent ministry separately issued technical specifications for its own purpose. Thus, the systematic coordination among ministries was insufficient. As a consequence, significant differences existed in the technical process, data accuracy, and classification system. Furthermore, spatial overlap and semantic conflict arose among technical data, an occurrence that often leads to right disputes in practice [33-35]. From the perspective of unifying the administration of natural resource assets and territory space planning, three aspects of technical unification must be attained, namely, unification of the registration book, technical standard, and information platform. This study attempts to propose a draft of national technical specifications for an information platform by analyzing legal provisions and technical specifications.

\subsection{User Requirements for the Information Platform}

On the basis of the above analysis of the documents issued by China's central government and the systematic retrieval and organizing of relevant legal provisions and technical specifications, the user requirements for the information platform are listed in Table 1. 
Table 1. User requirements for the information platform of natural resource administration.

\begin{tabular}{|c|c|c|}
\hline Code & Requirement & Impact \\
\hline R1 & $\begin{array}{l}\text { Uniform coding of } \\
\text { subject }\end{array}$ & $\begin{array}{l}\text { The coding of personal and organizational identity information complies } \\
\text { with the provisions of the law. An individual uses a uniform ID number } \\
\text { code or passport number code. An organization uses a uniform social credit } \\
\text { code. Subject information can interact with ID data from public security, } \\
\text { market supervision, and civil affairs departments. Confirmation of a } \\
\text { market subject is based on the general principles of civil law. }\end{array}$ \\
\hline $\mathrm{R} 2$ & $\begin{array}{l}\text { Title and powers of } \\
\text { property rights are } \\
\text { prescribed by law }\end{array}$ & $\begin{array}{l}\text { All property rights are prescribed by law. Furthermore, private rights are } \\
\text { prescribed by the property law, and public rights are prescribed by } \\
\text { administrative laws. }\end{array}$ \\
\hline R3 & $\begin{array}{l}\text { Delimitation and } \\
\text { adjudication of the } \\
\text { object conform to } \\
\text { technical specifications }\end{array}$ & $\begin{array}{l}\text { Delimitation and adjudication of the object shall follow the technical } \\
\text { specifications for surveying and mapping of various resources, such as } \\
\text { land, housing, forest, and grassland. }\end{array}$ \\
\hline $\mathrm{R} 4$ & $\begin{array}{l}\text { Uniform specification } \\
\text { of rights' source } \\
\text { documents }\end{array}$ & $\begin{array}{l}\text { Legal documents concerning the acquisition of the ownership and use right } \\
\text { of natural resources shall be governed by law. Collective ownership is } \\
\text { based on the certificate of rights issued during the land reform. The use } \\
\text { right is based on the transaction contract or administrative approval } \\
\text { documents of various resources, such as the transfer contract, allocation } \\
\text { decision, and administrative license. }\end{array}$ \\
\hline R5 & $\begin{array}{l}\text { Adaptable to future } \\
\text { legal reforms }\end{array}$ & The property right setting of the platform can adapt to future legal reform. \\
\hline R6 & $\begin{array}{l}\text { Adaptable to future } \\
\text { technical specification } \\
\text { changes }\end{array}$ & $\begin{array}{l}\text { Object surveying and adjudication can adapt to changes in future technical } \\
\text { specifications. }\end{array}$ \\
\hline R7 & $\begin{array}{l}\text { Data interactions across } \\
\text { organizations }\end{array}$ & $\begin{array}{l}\text { The natural resource administration system can interact with data from tax } \\
\text { authorities, municipal utilities, etc. }\end{array}$ \\
\hline R8 & $\begin{array}{l}\text { Uniform registration } \\
\text { book }\end{array}$ & Separate registration books are transferred to a national unified one. \\
\hline R9 & $\begin{array}{l}\text { Uniform registration } \\
\text { process }\end{array}$ & $\begin{array}{l}\text { Different registration processes for various resources are transferred to a } \\
\text { national unified one. }\end{array}$ \\
\hline R10 & $\begin{array}{l}\text { Uniform information } \\
\text { platform }\end{array}$ & $\begin{array}{l}\text { All scattered registration information platforms are integrated into a } \\
\text { national unified one. }\end{array}$ \\
\hline
\end{tabular}

\section{Property Right Structure of China's Natural Resources}

Figure 3 shows the inputs, and output of the analysis process of the rights structure. Jo Hensson summarized the characteristics of global cadastral systems and proposed the "subject-rights-object" model [36]. The property rights structure model of China's natural resources is established based on Jo Hensson's research result. The general practice worldwide classifies the property rights of natural resources into private and public rights [37-39]. China's private rights over natural resources are mainly stipulated by civil law, and public rights are stipulated by administrative law. To answer the proposed scientific questions and respond to reform requirements, this study conducted structural text analysis method, that is, comprehensively retrieving the relevant legal provisions of natural resource administration (Table A1 in the Appendix A), systematically organized the property subject, object, and rights of various property rights (Tables $\mathrm{A} 3$ and $\mathrm{A} 4$ in the Appendix A), and obtaining the rights structure of natural resources. 


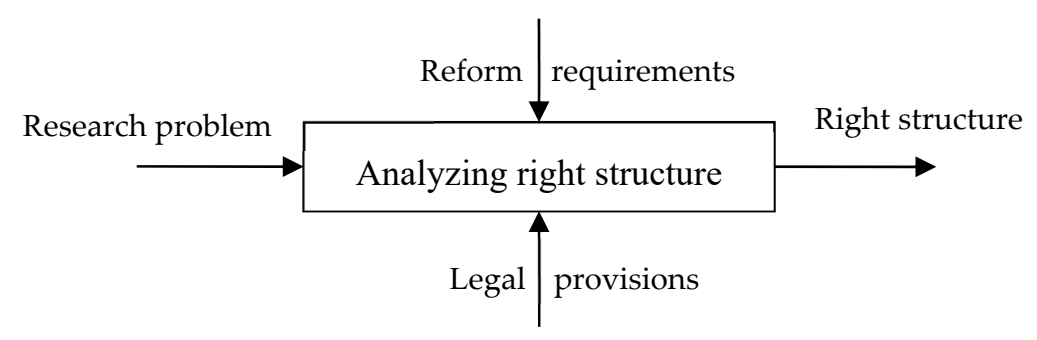

Figure 3. Inputs and output in the analysis process of the rights structure.

\subsection{Private Rights}

The analysis of the property right structure of the private rights of natural resources is mainly based on "property law", "provisional regulations on the registration of real estate", and "measures for the uniform adjudication and registration of the rights of natural resources (trial)." The types of property rights are organized from these provisions [40]. Furthermore, this research arranges the provisions on the subject, object, and rights individually from the legal provisions listed in Appendix A Table A1. China's Property Law belongs to the continental civil law system. Such a law divides real estate rights into ownership, usufruct rights, and security rights. This study analyzes the property structure of private rights according to this classification system.

\subsubsection{Ownership}

China's law stipulates public ownership of natural resources, that is, state or collective ownership [40]. In terms of land resources, the state ownership system is applied to the ownership of land in urban areas. The rural collective ownership system is generally applied to the ownership of land in rural areas and urban suburbs, except as otherwise provided by law [41]. The state may, in accordance with the law, expropriate or requisition collectively owned land and compensate for it for public interests [42]. In other words, the state may transfer land from collective ownership to state ownership for public interests. Mineral resources, waters, forests, mountains, grasslands, wastelands, beaches, and other natural resources are generally owned by the state, with the exception of those owned by collectives as stipulated by law. Private ownership of houses and other buildings, structures, and trees are permitted. State laws equally protect the property rights of public and private ownership. In the continental civil law system, ownership has a relatively complete set of rights. In compliance with space use regulations, ownership has the complete right of possession, use, profit, and transfer [43]. However, the law imposes special restrictions on rural collective ownership and does not allow rural collective economic organizations (collectives) to buy and sell land ownership.

\subsubsection{Usufruct Rights}

China exercises public ownership of natural resources. Therefore, the use of natural resources by individuals or organizations mainly depends on usufruct rights to provide the utilization conditions [41]. Usufruct rights derived from state ownership involve the rights of possession, use, profit, and transfer. Under the condition of payment, the qualification of the subject of rights is generally not limited. However, under the condition of free acquisition, the subject is limited to administrative organs or public welfare organizations. The usufruct right derived from collective ownership has the complete right of possession, use, and profit and the restricted right of transfer. The right to transfer is generally limited to the internal scope of rural collectives, and the subject of rights is limited to the members of rural collectives.

1. Right to use state-owned agricultural land. The object of the real right is a state-owned agricultural land, such as cultivated land, garden land, forestland, grassland, and a small area of water. The subject is a lawful citizen and organization. The rights over state-owned agricultural, forest, and pasture farms are permitted to be transferred to individuals or organizations through 
paid means, and the qualification of the right holder is not limited. The transferee of the right enjoys the right of possession, use, profit, and transfer in compliance with requirements of land use regulations. The subject of the right is restricted to developing and using the land for agricultural purposes.

2. Right to use state-owned construction land. The object of the real right is a state-owned construction land, such as residential, industrial, commercial, and other land. The subject is a lawful citizen and organization. When a local government transfers the right to an individual or organization by means of paid use, the qualification of the right holder is not restricted. The holder of the right is entitled to the right of possession, use, profit, and transfer under the condition of abiding by the provisions of land use control. The law strictly limits the scope of free allocation of land by local governments. Organizations that acquire the right to use freely allocated construction land are strictly limited to administrative or public welfare organizations. Given that the allocated use right is acquired without compensation, the law restricts the transfer of the right. However, the right to use the allocated construction land may be transferred to a third party after it has paid the land transfer fee in full according to relevant standards.

3. Breeding right on water area and beach. The object of the real right is a state-owned water area or beach. The subject is a lawful citizen and organization. In cases where the right is transferred to an individual or organization by means of compensation, the qualification of the right holder shall not be restricted. The right holder is entitled to the complete rights of possession, use, and profit and the restricted right of transfer under the condition of abiding by the provisions of land use control. The transfer of breeding right requires administrative approval from the fishery department. The right holder is restrained to using the water area and beach for aquaculture purposes.

4. Right to use sea areas. The object of the real right is a state-owned sea area, such as areas for cultivation, tourism, entertainment, and other uses. The subject is a lawful citizen and organization. The content of the right to use sea areas is similar to the use right of state-owned construction land. The difference is that the former requires administrative permission from the department in charge of marine affairs.

5. Right to use an uninhabited island. The object of the real right is a state-owned uninhabited island, such as an area for tourism and entertainment, transportation, industry, and other uses. The subject is any lawful citizen and organization. The content of the right to use an uninhabited island is similar to the right to use sea areas.

6. Mining Right. The object of this real right is the minerals in the specified depth range of surface, underground, or underwater. The subject is limited to an organization with a mining qualification. Mining right is the right to exploit mineral resources and obtain products mined within the scope stipulated in the mining license according to law. Such a right involves complete rights of possession, use, and profit and restricted transfer right. The transfer of mining right requires administrative approval from the concerned department of mineral resources. The mining right holder shall follow the rules of land or sea use regulation to control the ecological impact of mining activities on the land or marine environment.

7. Right to use forests and forestlands. The object of the real right is a state- or collective-owned forestland and attached forest. The subject is any lawful citizen and organization. Development and utilization of forests and forestlands are strictly restricted by law. Operators of timber stands, economic forests, and firewood forests are entitled to rights of management, profit, and other legitimate rights. Operators of shelterbelts and special forests have the right to obtain forest ecological compensation. The transfer of the right requires administrative approval from the concerned forestry authorities. The right holder is restricted to using the land for forestry purposes.

8. Right to land-contracted management. The object of the real right is a cultivated land, garden land, forest land, pasture, or water area owned by the collective. The subject is a member of a rural collective. Under the premise of agricultural utilization, the right holder shall have the right 
to independent production and operation. The Revised Rural Land Contracting Law allows for the transfer of the right to any individual and organization outside the rural collective. After the transfer, the transferee obtains the right to manage the land, and the contractor retains the right to contract the land. The right holder is restricted to using the land for agricultural purposes.

9. Right to use wasteland. The object of the real right is a collective-owned wasteland, such as a waste mountain, valley, hill, and beach land. The subject is any lawful citizen and organization. When a collective transfers the right to an individual or organization by means of compensation, the qualification of the right holder is not restricted. The right holder is entitled to complete rights of possession, use, profit, and transfer under the condition of abiding by the provisions of land use control. The right holder is limited to using the land for agricultural purposes.

10. Right to use collective-owned construction land. The object of the real right is a collective-owned construction land. The subject is a collective member or a subordinate enterprise. A rural collective is permitted to transfer the right with compensation or allocate the right without compensation to its members or subordinate enterprises for the development of non-agricultural industries, such as a rural industry. However, the law restricts a rural collective from transferring or allocating the right to individuals or organizations outside the collective. The right holder is entitled to relatively complete rights of possession, use, and profit under the condition that the holder abides by the provisions of land use regulation. The transfer right of the use right is incomplete. Laws do not allow the right holder to transfer the right to individuals or organizations outside the collective. However, in the case of poor management by the right holder, the land may be used as a factor of production to conduct cooperative management with individuals or enterprises outside the collective.

11. Right to use homestead land. The object of the real right is a rural homestead land, that is, a land for building a house in the countryside. The subject is a member of a rural collective. The rural collective freely allocates the right to an internal householder for building a house. The right holder shall develop and utilize the homestead land in accordance with the requirements of land use control. The right holder also has the right to possess, use, and profit. Furthermore, the right holder may lease the right on the premise that it does not violate the requirements of land use control. The right may be transferred to a member of the collective, but not to an individual or organization outside the collective.

12. Easement. The object of the real right is the servitude agreed in the easement contract. The subject is any lawful citizen and organization. Easement is the right to use other's real estate to improve the benefit of his/her own real estate according to the contract. The easement shall not be transferred or mortgaged separately. When the land-contracted management right, the right to use construction land, or the right to use homestead land is transferred or mortgaged, the easement shall be transferred or mortgaged together, except as otherwise agreed in the contract.

\subsubsection{Security Right}

Mortgage is the only security right of natural resources. The object of the property right is the land stipulated in the mortgage contract. The subject is a legal financial organization. Mortgage is the right that entitles the creditor to dispose of the mortgaged property with the right of change in price and the right of priority to receive compensation when the debtor fails to pay the debt by the expiration date or the mortgage agreed upon by the parties is realized [40]. The mortgage is based on the premise that the creditor does not transfer the secured property possessed by the debtor or the third party. Usufruct rights that can be mortgaged include the right to use state-owned agricultural land, right to use state-owned construction land, breeding right on a water area and beach, right to use sea areas, right to use an uninhabited island, mining right, right to use forests and forestlands, and land-contracted management right. 


\subsection{Public Rights}

The current laws have established the planning of space use control, such as comprehensive land use planning (land planning), urban and rural planning (U\&R planning), and sea use planning (sea planning) [44]. Comprehensive land use planning is an overall arrangement in time and space for the development, utilization, and protection of land resources within a certain area. The main purpose of formulating and implementing land planning is to control construction land sprawl, protect agricultural and ecological lands, and implement special measures to protect cultivated land. Accordingly, land planning adopts dual control measures, that is, land use quotas (control of construction land and protection of agricultural land) and land use zoning. Quantity control of land use quotas is implemented in the spatial layout of land use zoning. U\&R planning is the overall arrangement of the scale, structure, layout, and sequence of urban and rural construction. The purpose of formulating and implementing $\mathrm{U} \& \mathrm{R}$ planning is to create a pleasant living environment and provide equitable infrastructure services. $U \& R$ planning controls the development and utilization of space through intensity control of space development and utilization and configuration of infrastructure-supporting conditions. Sea planning is used to guide and restrict marine development and utilization activities by defining different types of marine functional zones. The motivation of sea planning is to control the scale and layout of the sprawl of non-ecological sea areas and strictly protect the sensitive and fragile areas of marine ecology.

Land, U\&R, and sea planning are based on space use zoning for space use regulation. Moreover, they all propose provisions for permitted, restricted, and prohibited uses within the zoning and administrative penalties for violation $[45,46]$. The objects of the three plans are the lands, sea areas, or beaches within the space use zone. Their subjects are the holders of the private rights of the lands, sea areas, or beaches within the zone. The right holders may develop and utilize the space according to the corresponding use control rules of the zone. China's central government has proposed a policy of integrating land, $U \& R$, and sea planning into territory space planning (space planning).The Standing Committee of NPC has listed the Law of Territory Space Planning in the national legislative plan. Furthermore, the Ministry of Natural Resources has initiated the drafting of planning measures and technical regulations at the request of the central government. According to the drafted measures and procedures, urban, rural, and marine areas shall adopt the land or sea use zoning system of land planning, U\&R planning, and sea planning, respectively, in the preliminary integration stage. The objects, subjects, and rights of space planning are similar to those of the three plans mentioned above.

\subsection{Overview of the Property Rights Structure of China's Natural Resources}

The property rights model of China's natural resources is formed by summarizing the aforementioned analysis, including the subject, rights, and objects of properties (Figure 4) [36]. Subjects are divided into state, rural collectives, individuals, and organizations. Objects are divided into two parts: Earth surface and fixture. Earth surface objects are further categorized into land, sea, and island. Fixtures are categorized into houses, forests, and minerals. Meanwhile, rights are divided into private and public. Private rights are categorized into ownership, usufruct rights, and security rights. Public rights are categorized into comprehensive land use planning and territory space planning. 


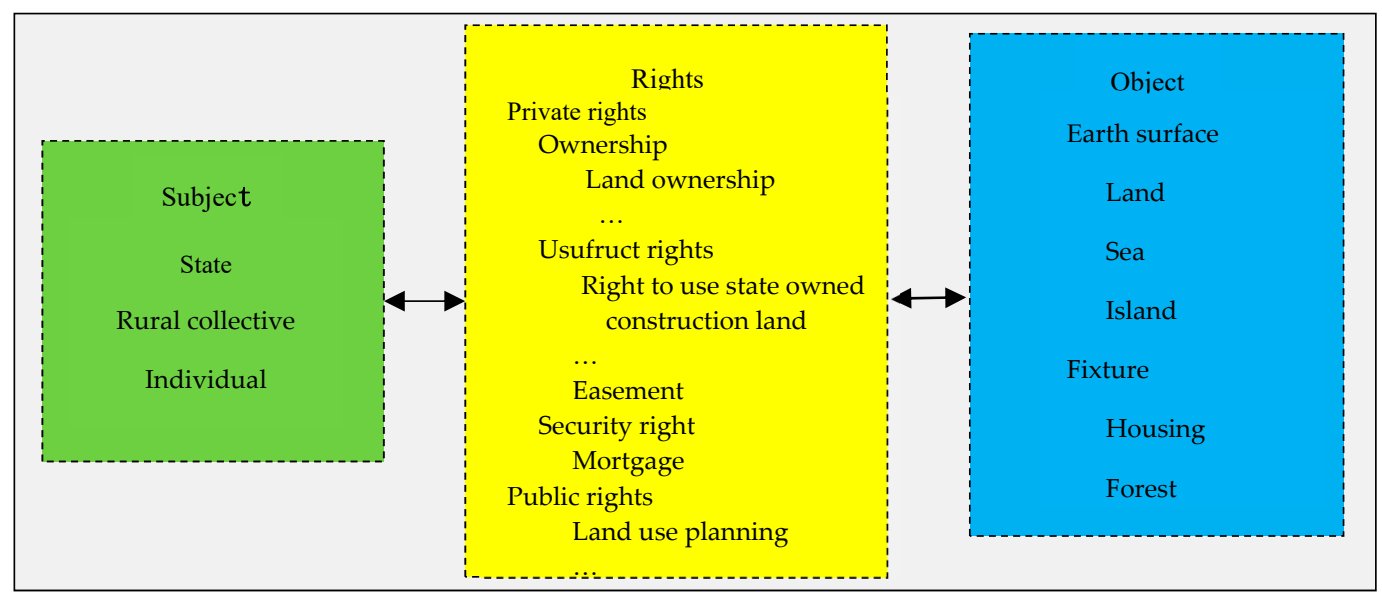

Figure 4. Property rights structure of China's natural resources.

\section{Natural Resource Administration Domain Model in China}

Figure 5 shows the inputs and output of the process of developing the domain model. To meet the requirements of LADM and the provisions of technical standards, this section uses the object-oriented development method based on UML to convert the property rights structure into a domain model and conceives a technical standard draft for China, namely, CN_NRADM (CN_NRADM is the abbreviation of the Chinese Natural Resource Administration Domain Model) (Figure 5).

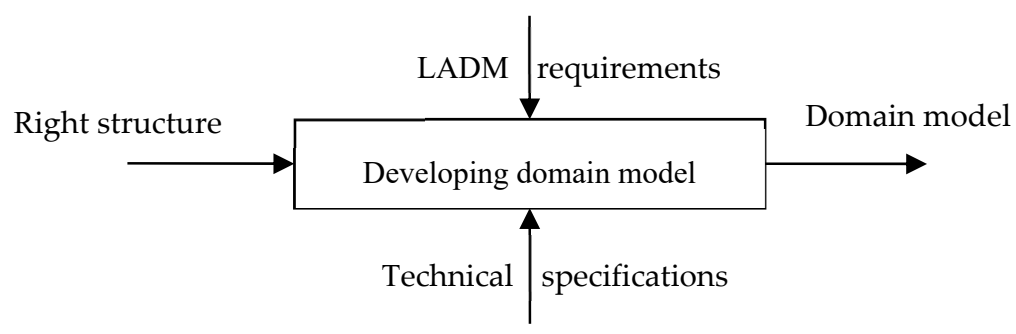

Figure 5. Inputs and output of the analysis process of developing the rights structure.

Figure 6 shows the core classes and associations in CN_NRADM. LADM is a common academic semantics created by the international land management science community to promote effective academic communication within the international academic community by using a uniform terminology [10]. In terms of theory, this standard is beneficial for reducing the theoretical confusion and misunderstanding caused by the confusion of terms, fostering a theoretical paradigm that is accepted by the academic community, and promoting knowledge accumulation based on a common paradigm [15,47]. In terms of practice, LADM is valuable for decreasing the development cost of a land administration system by avoiding the phenomenon of "making a wheel repeatedly" [13]. LADM is also conducive to the interconnection and integration of the land administration system and its external related systems, thereby avoiding the so-called "information island" or "digital divide". Therefore, LADM can improve the systematic governance of resource issues [48]. Given that LADM has created an internationally uniform conception and standard, it is conducive to the continuous improvement of land through foreign direct investment [6]. The basic components of LADM correspond closely to those of Jo Hensson's "subject-rights-object" model [10]. The Party Package, the Administrative Package, and the Spatial Unit Package (including the subordinate Surveying and Representation Sub-package) correspond to subject, rights, and object, respectively. It is notable that OGC LandInfra and its sub package OGC LandDivision absorbs the academic conceptions of LADM and proposes a series of classes responding to core classes of LADM and associations between them. Furthermore, LandInfra deepens the study of land division and further proposes the module of condominium which focuses 
on building and construction spatial information. The article attempts to absorb the core conceptions of LandInfra, specially the design ideas of the condominium part.

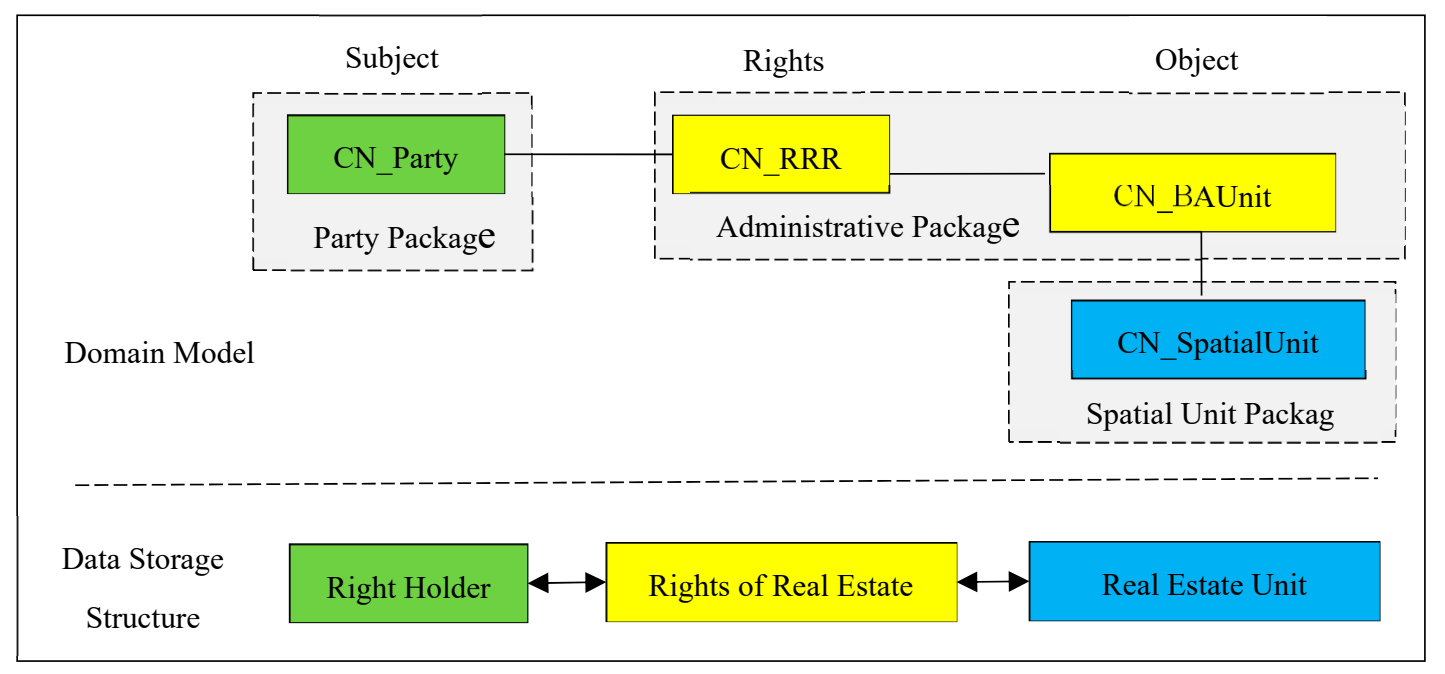

Figure 6. Core classes and their associations in the CN_NRADM model.

The evolution of institution and technology is path-dependent [49]. The development of new technical standards should not only inherit the beneficial parts of the previous regulations and technical specifications, but also make necessary innovations according to the actual development demands. This study conceives the classes and attributes in CN_NRADM according to technical specifications to effectively connect the model with the provisions of the "standards for real estate registration database", "rules for setting and coding real estate units", and "working plan for adjudicating and registering property rights of natural resources." The "standards for real estate registration database" is a national standard for the data storage structure of a real estate registration system and strictly regulates real estate entities and relationships. The standard covers basic geographic information, administrative areas, raster images, real estate registration elements, and other components. The real estate registration elements that are closely related to CN_NRADM include real estate subjects, rights, registration units, and processes. The real estate process belongs to the field of dynamic models and is beyond the scope of this article. This work focuses on the three parts of real estate: subjects, rights, and registration units. The "rules for setting and coding real estate units" is a supplement to the division of real estate units and provides an important reference to the BaUnit class and Spatial Unit class in CN_NRADM. The "working plan for adjudicating and registering the property right of natural resources" is a supplementary provision for adjudicating and registering ownership and usufruct rights of state-owned natural resource assets. The plan pays particular attention to the designation and protection of ecological resources, such as water flows.

\subsection{Party Package}

The Party Package corresponds to the "subject" in the "subject-rights-object" model (Figure 7). In the Party Package, Party is an important class for describing individuals. PartyGroup is a subclass of Party used to describe a group. PartyMember is an association class for describing the composition relationships that individuals form in a group. In the case of a separate possession of a natural resource asset, the subject is described using Party. In the case of co-ownership of a natural resource asset, the subjects are presented as a PartyGroup. The Property Law stipulates that co-ownership of property rights can be divided into common joint-ownership and joint ownership by share. PartyMember can be used to present a composition relationship of co-ownership by common or by shares. According to the general principles of Civil Law, the Party includes the following types: State, rural collectives, natural persons, governments, public welfare organizations, enterprises, and unincorporated organizations. 
The state and rural collectives are the subjects of ownership. Moreover, natural persons, governments, public institutions, enterprises, and unincorporated organizations are the subjects of usufruct rights and security right. Owing to the different restrictions of various property rights on the subject, corresponding restrictions are set on the association between Party and RRR according to the research in Section 3.

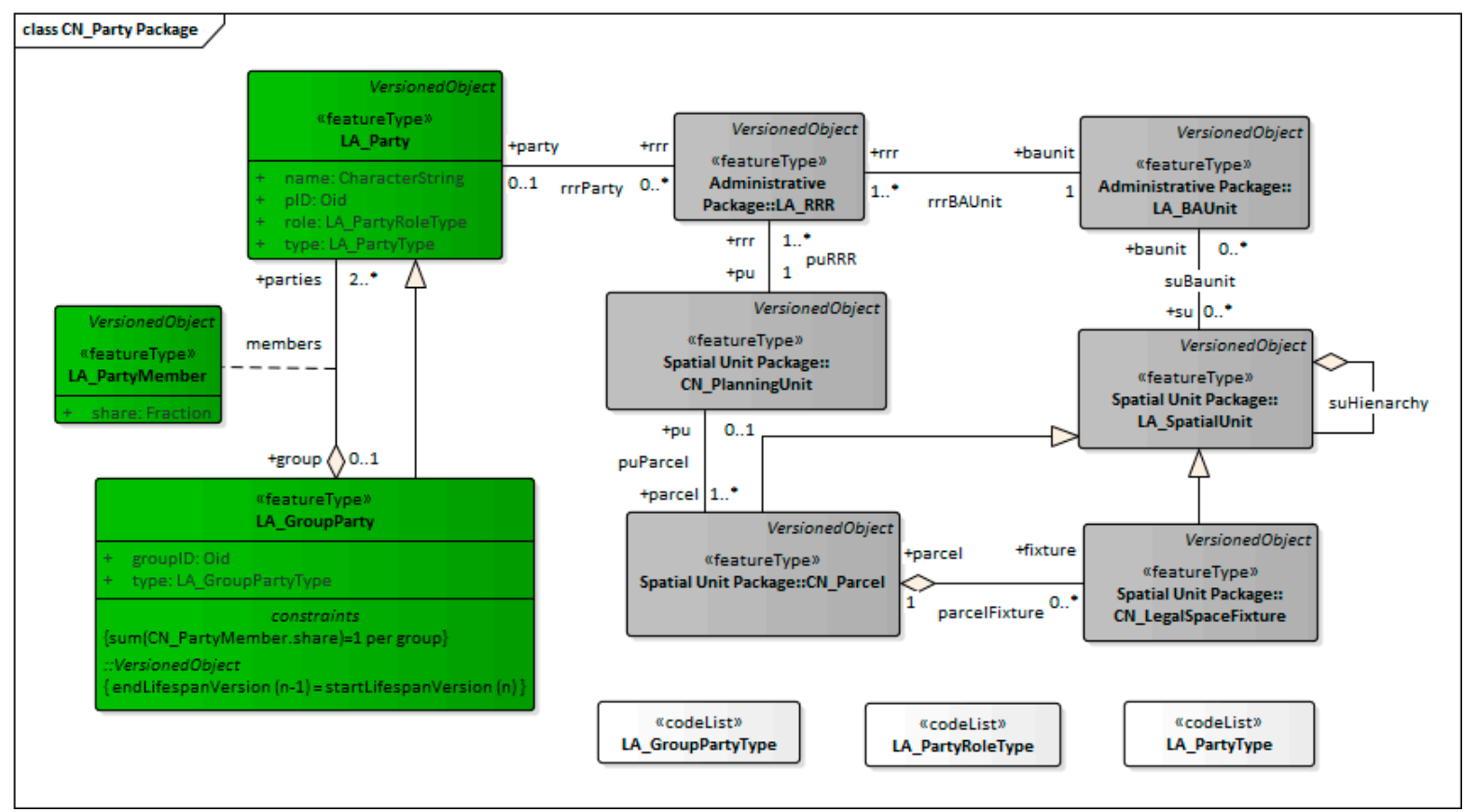

Figure 7. Party Package with Relationship ("green" part).

\subsection{Administrative Package}

The Administrative Package corresponds to the "rights" in the "subject-rights-object" model (Figure 8). RRR and BAUnit are the two most important classes in this package. RRR is an abstract class that defines property and derives subclasses, such as Rights, Responsibilities, and Restrictions. According to the research results in Section 3, most private and public rights are collected into Rights and Restrictions, respectively. (1) Both ownership and usufruct rights are derived from Rights. Ownership can be divided into national, collective, and individual ownership. The corresponding types are set in the codlist Ownershiptype. Moreover, various subclasses, such as the right to use state-owned agricultural land, right to use state-owned construction land, breeding right on water areas and beach, right to use sea areas, right to use uninhabited islands, mining right, right to use forests and forestlands, right to land-contracted management, right to use wasteland, right to use homestead land, and easement, are derived from usufruct rights. (2) Mortgage and space regulation rights are derived from Restrictions. Furthermore, land planning, U\&R planning, sea planning and space planning are created under the CN_SpatialRegulation. Since space control is mainly a kind of restriction from public right to private right, the planning classes are all derived from the restriction class. At present, the comprehensive land use planning, urban and rural planning and sea use planning are all in operation. Each has its own independent management system and procedures. Therefore, this administration information needs to be managed separately and kept for future archival traceability. For future consideration, the spatial planning class is proposed as a placeholder to manage information of planning quotas and spatial uses. By 2020, comprehensive land use planning, urban and rural planning, and sea use planning will stop running. At that time, territory space planning will play a role in their place.

The BAUnit is used to present the unit of property rights under the same property right. LA_BAUnit is employed as the class of a natural resource property right unit in this study. In terms 
of private rights, registration units of lands or sea areas shall be determined according to the source documents of ownership or usufruct right (certificate of rights, transfer contract, allocation decision, land contract, etc.) according to the provisions of the "rules for the establishment of real estate units and code compilation." Units of buildings, structures, and other fixtures are divided according to certain principles, such as fixed and closed boundaries and independent use of space with a complete function. Forest and trees are divided into a registration unit according to the principle that continuous forest or trees (or individual trees) belong to the same owner. Dividing the other types of fixtures independently according to their types and ownership is advised. As for public rights, space use zoning of all kinds of space planning is defined in the division units of LA_BAUnit. Land planning consists of various zoning types for land use control, such as primary farmland protection area, urban construction area, village construction area, and forestry area. U\&R planning consists of numerous zoning types for construction use control, such as residential land, land for public administration and service, land for commercial service facilities, and industrial land. Sea planning consists of several zoning types for sea use control, such as port and shipping area, fishery resource utilization and conservation area, mineral resource utilization area, tourist area and reservation area.

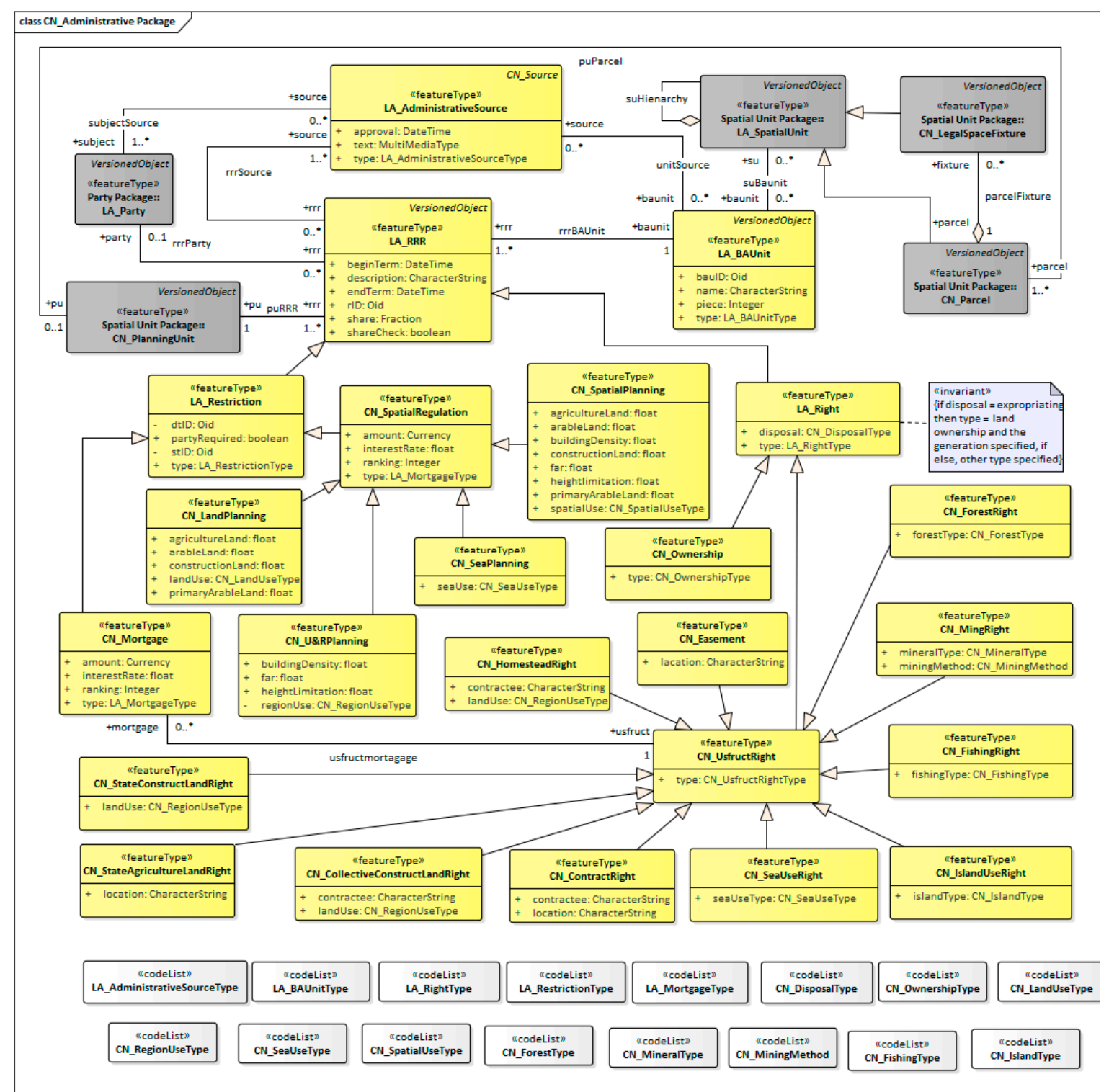

Figure 8. Administrative package with Relationship ("yellow" part). 


\subsection{Spatial Unit Package}

The Spatial Unit Package corresponds to the "object" in the "subject-rights-object" model (Figure 9). Spatial Unit mainly consists of Parcel, Fixture, and Planning Unit according to the regulations of the real estate units in the "standard for real estate registration database." (1) Parcel is a class used to present the surface of the Earth. Subclasses, such as "Land Parcel" and "Sea and Island Parcel", can be further derived from the Parcel class, These subclasses describe the spatial representation of units for land administration, marine administration, and island administration. Given that China exercises public ownership of natural resource, parcel is the basic surveying unit of adjudication and demarcation for ownership of natural resources and the right to use natural resources. (2) Fixture is an abstract class used to present attachment fixed on the surface of the Earth. Subclasses, such as "Building", "Structure", can be further derived from the Fixture class. These subclasses describe the spatial representation of units for buildings (houses), structures, and other fixed objects, such as forests and minerals. Considering that China's property law stipulates that fixture can be owned by individuals, fixture is the basic surveying unit of adjudication and demarcation for ownership of fixed objects. (3) Planning unit is a basic surveying and map unit for spatial planning, that is, a zone of land, sea or island with similar spatial control measures for public rights [26]. In addition, planning unit block presents a spatial planning map of a city, town or village. Thus, several planning units compose a planning unit block. (4) Given that a house has a complex 3D utilization relation, a building (house) is created with the logic relation "building-logic building-floor-room." The 3D utilization relation is presented by the vertical direction lifting model based on the 2D parcel. (5) The compositional relationship between parcel and fixture and the association relationship between parcel and planning unit are presented.

Notably, the real estate unit part of the "standard for real estate registration database" subdivides buildings (real estate) according to the logical relationship of "building-logical building-floor-room," which is an inheritance from the "standard for basic information data of real estate market" of the former Ministry of Construction. This feature is conducive to the integration of the housing registration data of the former ministry. In terms of applicability, most Chinese buildings can be adjudicated and registered in this way, which is conducive to reducing the operation cost of the real estate registration system. Therefore, it is a practical and effective technical solution. This research designs the classes related to a building, such as CN_LegalSpaceBuidling and LA_LegalSpaceBuildingUnit, according to the requirements of the "standard for real estate registration database" but does not adopt the real 3D cadastral design technology. 


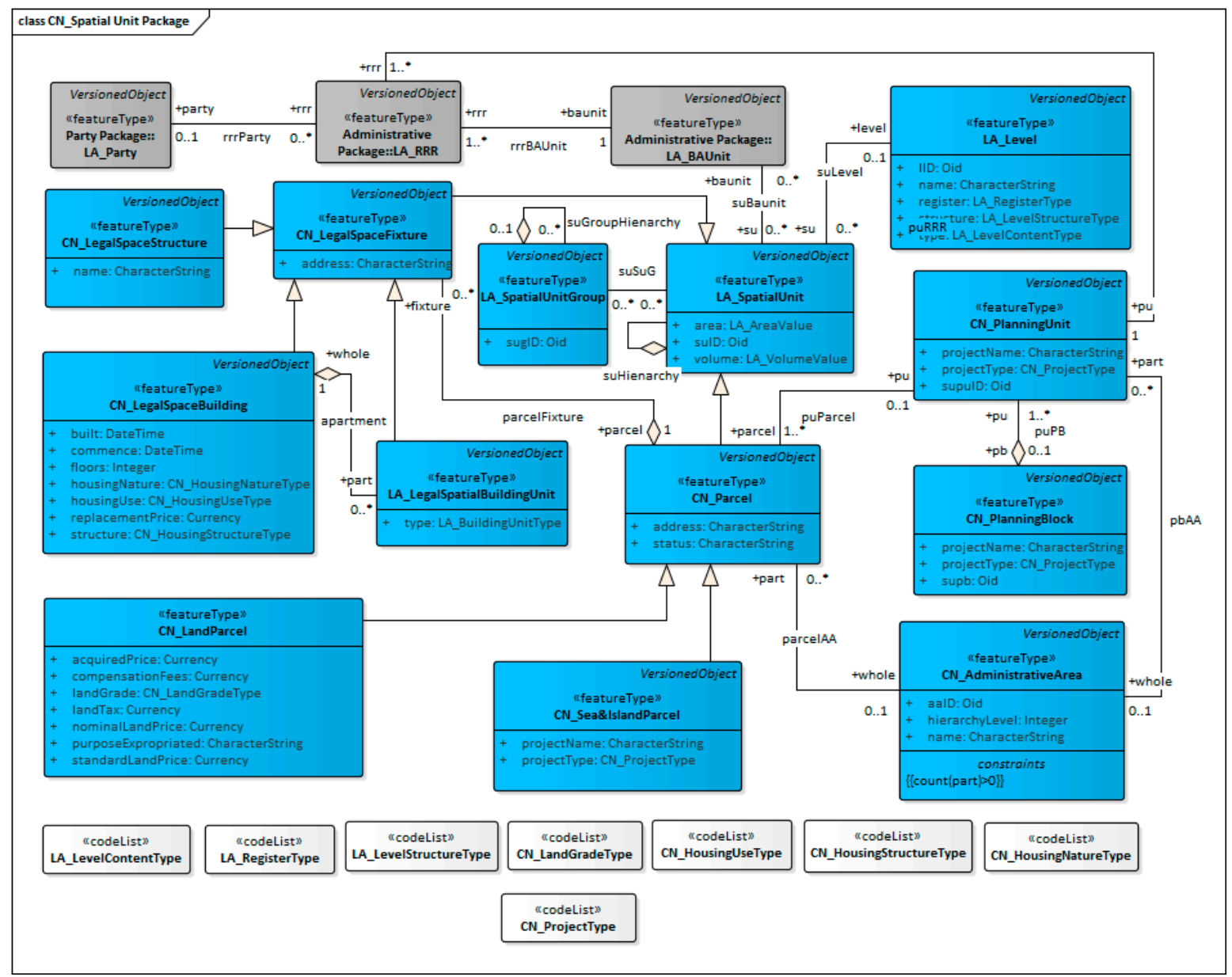

Figure 9. Spatial Unit Package with Relationship ("blue" part).

\subsection{Surveying and Representation Sub-Package}

The geographical data of the newly established information platform of natural resource administration is acquired by integrating the surveying and representation data produced on the basis of existing technical specifications of various ministries. Before the new technical specifications are issued, the surveying and representation data of various natural resources will still be managed according to the existing technical specifications. Appendix A Table A2 lists the existing technical specifications for the registration of natural resource assets, which serve as the basis for the design of each class of this package. Boundary points constitute BoundaryFaceString, and the BoundaryFaceStrings in turn constitute Spatial Unit, such as the AdministrativeArea, Parcel, and Fixtures. The newly established Ministry of Natural Resources is responsible for the administration of surveying, mapping, and geographic information to: (1) Receive the registration data of natural resource assets handed over by other ministries and commissions and collate and record the data and files; (2) conduct data cleaning on the transferred data and process gaps, errors, and overlapping data according to legal procedures. If necessary, the ministry shall conduct another investigation to adjudicate and register the right; (3) perform data conversion according to the semantic correspondence between the original database and the unified real estate registration database. The converted data shall be incorporated into the unified real estate registration database after passing the quality test; and (4) perform coordinate transformation of surveying and representation data. The data of the Xi'an 54 coordinate system and Beijing 80 coordinate system are uniformly converted to the Beijing 2000 coordinate system. The codelist LA_Transformation plays a key role in the transformation of the coordinate system (Figure 10). 


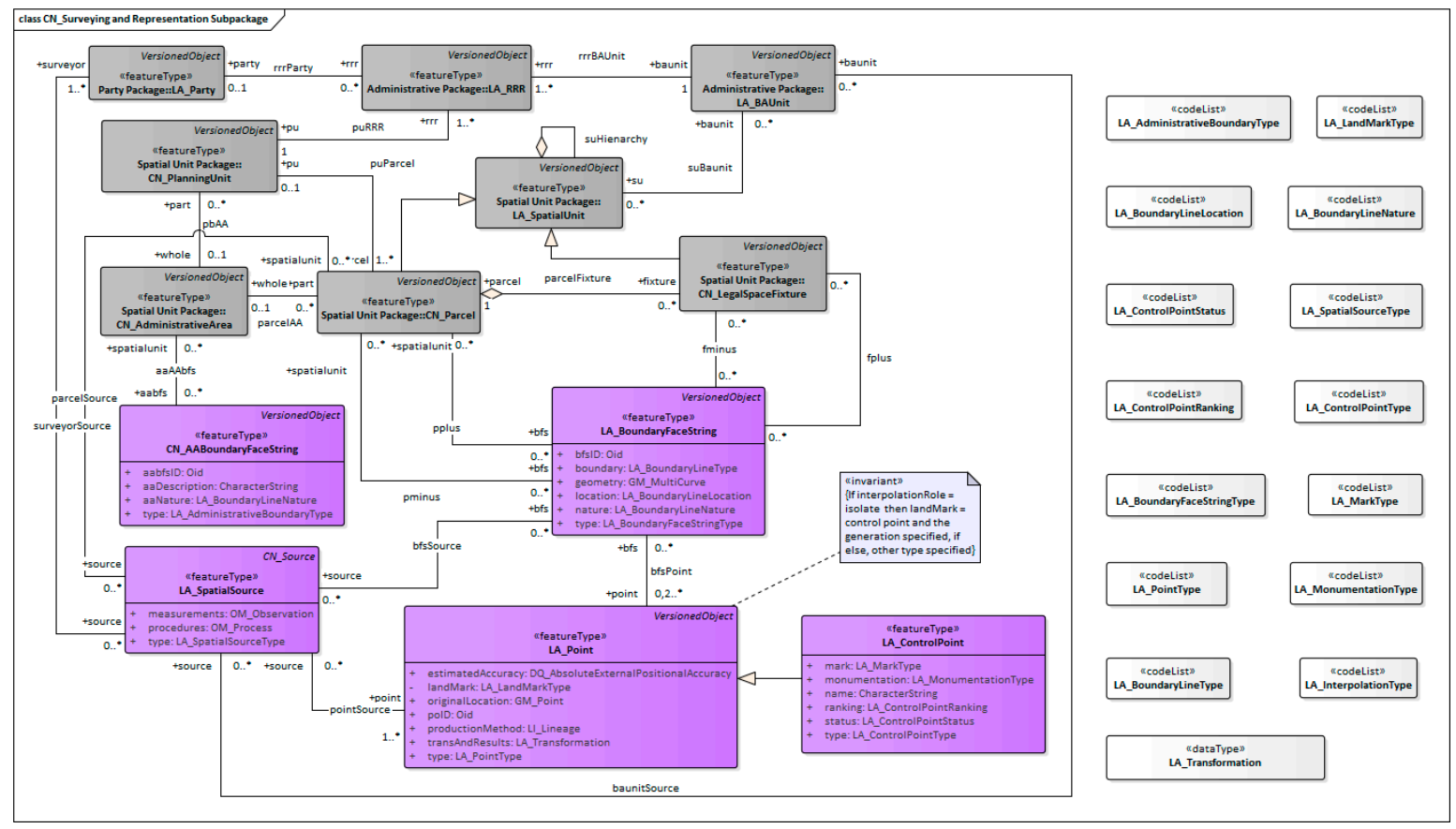

Figure 10. Surveying and Representation Sub-package with Relationship ("purple" part).

\section{Conclusions and Discussions}

This section examines the research problem, the reform requirements, and the domain model to draw several conclusions. Figure 11 illustrates the inputs and output in the process of drawing conclusions. Furthermore, the comparative research method is conducted in the process. The research problem in this work involves the development of a draft technical standard of natural resource administration that conforms to the LADM standard and meets the demands of unified administration of natural resources in China. The requirements of the natural resource administration reform consist of the establishment of unified legal stipulations, unified administrative institutions, and unified technical standards. In terms of technical standards, a unified terminology, a unified registration book, a unified registration process, and a unified information platform are necessary. Table 2 lists the user requirements of the information platform.

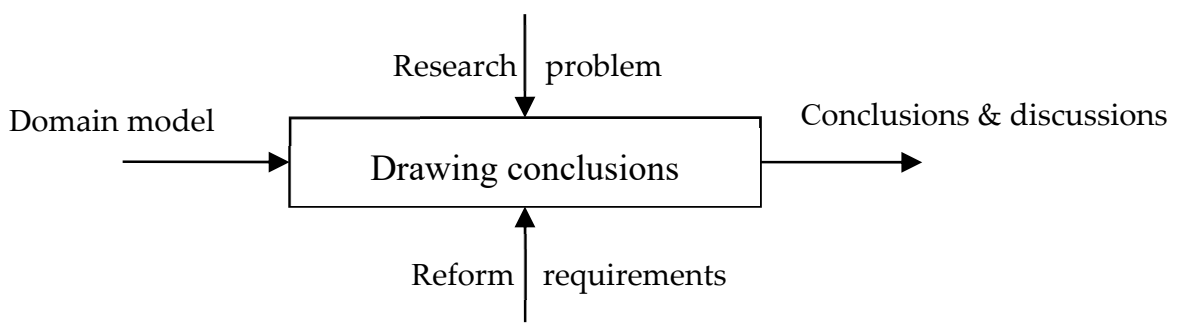

Figure 11. Inputs and output of analysis process of drawing conclusions.

Based on such a problem and requirements, this study analyzes the property rights structure of China's natural resource assets and develops a property rights model of China's natural resources by organizing the legal text of China's natural resource administration. Furthermore, this research uses an object-oriented design method to convert the property rights model into a domain model and produces a draft national technical standard of China's natural resource administration. Therefore, this work answers the scientific question raised by the research. Table 2 indicates the responsiveness of the research results to the user requirements of the platform. Most requirements are adequately addressed, with the exception of the unresponsive requirements of the unified registration process (Table 2). The 
unified registration process belongs to the content of dynamic modeling and is beyond the scope of this study.

Three deficiencies in this study must be studied in the future. First, given that the legal and technical systems of natural resource administration in China are undergoing reform, the results of this study present only a draft of the technical framework for the construction of a unified information platform in response to the reform of natural resource administration. This draft framework must be extended according to the improvement of the subsequent legal and technical systems. Second, considering that LADM standard is undergoing the revision stage of the second edition according to the working plan of ISO and FIG, this study is necessary to be deepened and extended according to the core newly added modules of LADM second edition (e.g., valuation, spatial planning and real estate transaction) $[25,26]$. For examples, the current accounting of natural resource assets and liabilities carried out by the ministry of natural resources requires the in-depth study of natural resource valuation and taxation model [50]. The relevant model of territory space planning is required to be improved and revised according to the framework of the LADM second edition. In addition, dynamic models of natural resource administration also deserve further study [51]. Last, considering that China's natural resource reserves increasingly tighten the constraints on economic and social development, strengthening the 3D utilization of resources could be a future trend. The demand for 3D cadastral administration of houses and other buildings, minerals, water areas, and other natural resources is becoming increasingly urgent. However, considering that the construction of China's natural resource administration system is still at the initial stage, the development of a 3D cadastral system requires substantial investment. This work does not discuss the 3D administration system in depth.

Table 2. Responsiveness of the domain model to user requirements.

\begin{tabular}{|c|c|c|c|}
\hline Code & Requirement & $\begin{array}{l}\text { Responsiveness of } \\
\text { the Model }\end{array}$ & Relevant Package and Classes \\
\hline R1 & Uniform coding of the subject & Complete & Party package: CN_Party \\
\hline $\mathrm{R} 2$ & $\begin{array}{l}\text { Title and powers of property } \\
\text { rights are prescribed by law }\end{array}$ & Complete & $\begin{array}{l}\text { Administrative package: CN_RRR and its } \\
\text { subclasses }\end{array}$ \\
\hline R3 & $\begin{array}{l}\text { Delimitation and adjudication } \\
\text { of the object conform to } \\
\text { technical specifications }\end{array}$ & Complete & $\begin{array}{l}\text { Spatial unit package: CN_Parcel, } \\
\text { CN_Fixture, and their subclasses }\end{array}$ \\
\hline $\mathrm{R} 4$ & $\begin{array}{l}\text { Uniform specification of rights' } \\
\text { source documents }\end{array}$ & Complete & $\begin{array}{l}\text { Administrative package: } \\
\text { CN_AdministrativeSource }\end{array}$ \\
\hline R5 & $\begin{array}{l}\text { Adaptable to future legal } \\
\text { reforms }\end{array}$ & Complete & $\begin{array}{l}\text { Administrative package: } C N \_R R R \text { and its } \\
\text { subclasses }\end{array}$ \\
\hline R6 & $\begin{array}{l}\text { Adaptable to future technical } \\
\text { specification changes }\end{array}$ & Complete & $\begin{array}{l}\text { Spatial unit package: CN_Parcel, } \\
\text { CN_Fixture and their subclasses }\end{array}$ \\
\hline R7 & $\begin{array}{l}\text { Data interactions across } \\
\text { organizations }\end{array}$ & Complete & $\begin{array}{l}\text { Party package, Administrative package, } \\
\text { Spatial unit package, and their relevant } \\
\text { classes }\end{array}$ \\
\hline $\mathrm{R} 8$ & Uniform registration book & Complete & $\begin{array}{l}\text { Party package, Administrative package, } \\
\text { and their relevant classes }\end{array}$ \\
\hline R9 & Uniform registration process & Blank & Null \\
\hline R10 & Uniform information platform & Complete & Domain model \\
\hline
\end{tabular}

Author Contributions: This research is a result of the collaboration and contribution of all authors. Conceptualization, Zhongguo Xu and Guan Li; formal analysis, Rong Liao, Cifang Wu and Yuzhe Wu; methodology, Yuefei Zhuo; software, Yuefei Zhuo; writing—original draft, Zhongguo Xu; writing—review and editing, Guan Li. All authors read and approved the final manuscript.

Funding: This research was funded by the Key Program of National Social Science Foundation of China grant number 14ZDA039. 
Conflicts of Interest: The authors declare no conflict of interest.

\section{Appendix A}

Additional supporting information may be found in the Appendix of this article. The Appendix includes additional information on the legal system of natural resource administration in China (Table A1 in the Appendix A), technical specifications for natural resource asset registration (Table A2 in the Appendix A), structure of the private rights of natural resource assets (Table A3 in the Appendix A), and structure of public rights of natural resource assets (Table A4 in the Appendix A).

Table A1. Legal system of natural resource administration in China.

\begin{tabular}{|c|c|}
\hline Legal Level & Legal Title \\
\hline 1 Constitution & Constitution (National People's Congress, 2018 Amentment) \\
\hline \multirow[b]{2}{*}{2 Law } & $\begin{array}{l}\text { Comprehensive: property law (Order of the President No. 62, 2007), security law (Order } \\
\text { of the President No. 50, 1995) }\end{array}$ \\
\hline & $\begin{array}{l}\text { Special: land administration law (Order of the President No. 32, } 2019 \text { Amentment), urban } \\
\text { real estate administration law (Order of the President No. 32, 2019 Amentment), mineral } \\
\text { resources law (Order of the President No. 18, } 2009 \text { Amentment), agricultural law (Order } \\
\text { of the President No. 74, } 2012 \text { Amentment), land contract law (Order of the President No. } \\
\text { 17, } 2018 \text { Amentment), forest law (Order of the President No. 18, } 2009 \text { Amentment), } \\
\text { grassland law (Order of the President NO. 5, } 2013 \text { Amentment), water law (Order of the } \\
\text { President No. 48, 2016 Amentment), sea use administration law (Order of the President } \\
\text { No. 61, 2001), fisheries law (Order of the President No. 25, 2013 Amentment), urban and } \\
\text { rural planning law (Order of the President NO. 29, } 2019 \text { Amentment) }\end{array}$ \\
\hline \multirow[b]{2}{*}{$\begin{array}{l}3 \text { Administrative } \\
\text { regulations }\end{array}$} & $\begin{array}{l}\text { Comprehensive: provisional regulations on the registration of real estate (Order of the } \\
\text { State Council NO. 710, } 2019 \text { Amentment) }\end{array}$ \\
\hline & $\begin{array}{l}\text { Special: regulations for implementing the land administration law (Order of the State } \\
\text { Council No. 653, } 2014 \text { Amentment), regulations for protecting primary farmland (Order } \\
\text { of the State Council No. 588, 2011 Amentment), detailed rules for implementing the } \\
\text { mineral resources law (Order of the State Council No. 152, 1994), regulations for } \\
\text { implementing the forest law (Order of the State Councile No. 698, } 2018 \text { Amentment), } \\
\text { regulations for river course administration(Order of the State Council No. 687, 2017 } \\
\text { Amentment), regulations for nature reserves(Order of the State Council NO. 687, } 2017 \\
\text { Amentment), regulations for protecting aquatic wildlife (Order of the State Council No. } \\
645,2013 \text { Amentment), regulations on the exploitation of offshore oil resources in } \\
\text { cooperation with foreign countries (Order of the State Council NO. 607, } 2011 \\
\text { Amentment), regulations on environmental protection for offshore oil exploration and } \\
\text { development (Order of the State Council NO. 202, 1983), measures for registration of } \\
\text { mining rights of mineral resources (Order of the State Council No. 653, 2014 Amentment) }\end{array}$ \\
\hline \multirow[b]{2}{*}{$\begin{array}{l}4 \text { Department } \\
\text { regulations }\end{array}$} & $\begin{array}{l}\text { Comprehensive: detailed rules for implementing provisional regulations on real estate } \\
\text { registration (Order of the Ministry of Natural Resources NO. 5, } 2019 \text { Amentment) }\end{array}$ \\
\hline & $\begin{array}{l}\text { Special: land registration measures (Order of the Ministry of Land and Resources No. 40, } \\
\text { 2007), housing registration measures (Order of the Ministry of Construction NO. 168, } \\
\text { 2008), measures for registration of land contracted management right (Order of the } \\
\text { Ministry of Agriculture No. 33, 2003), measures for registration of real rights of trees and } \\
\text { forestland(Order of the State Bureau of Forest No. 26, 2011), measures for registration of } \\
\text { breeding rights on water areas and beaches (Order of the Ministry of Agriculture No. 9, } \\
\text { 2010) }\end{array}$ \\
\hline $\begin{array}{l}5 \text { Administrative } \\
\text { documents }\end{array}$ & $\begin{array}{l}\text { Operation standard of real estate registration (the Ministry of Land and Resources NO. 6, } \\
\text { 2016), measures for registration of right to use sea areas (the State Bureau of Ocean No. } \\
\text { 28, 2006), detailed rules for implementing the fisheries law (the Ministry of Agriculture, } \\
\text { Animal Husbandry and Fisheries, 1987), uniform measures for adjudicating and } \\
\text { registering natural resource rights (the Ministry of Land and Resources No. 192, 2016), } \\
\text { and provisions for adjudicating ownership and land use right (the State Bureau of Land } \\
\text { Administration No. 26, 1995) }\end{array}$ \\
\hline
\end{tabular}


Table A2. Technical specifications for natural resource asset registration.

\begin{tabular}{cl}
\hline Specification Level & \multicolumn{1}{c}{ Specification Title } \\
\hline \multirow{3}{*}{ 1 National Standard } & $\begin{array}{l}\text { Classification and code of basic geographic information elements (GB/T 13923), } \\
\text { housing survey specifications (GB/T 17986), classification of land use (GB/T 21010), } \\
\text { specifications for forest resources planning and investigation (GB/T 26424), guidelines } \\
\text { for marine functional zoning (GB/T17108-2006), standard for urban land classification } \\
\text { and construction land planning (GBJ137-90) }\end{array}$ \\
\hline & $\begin{array}{l}\text { Cadastral survey standard (TD/T 1001), standard for urban cadastral database (TD/T } \\
\text { 1015), technical specification for a housing market information system (CJJ/T 115), } \\
\text { building coding standard (JGJ/T 246), standard for basic information of the housing } \\
\text { 2 Department } \\
\text { Standard } \\
\text { sea use (HY/T 123), standard for sea cadastre survey (HY/T 124), coding rules for } \\
\text { elements of rural land contracted management rights (NY/T 2538), specification for } \\
\text { adjudication and registration of rural land contracted management rights (NY/T 2539), } \\
\text { rules for compilation of comprehensive land use planning at the township level } \\
\text { (TDT1025-2010) }\end{array}$ \\
\hline S Department \\
Guidelines & $\begin{array}{l}\text { Survey of real estate (trial), technical provisions for investigation of rural collective land } \\
\text { ownership, rules for real estate unit setting and code compilation (trial), working plan } \\
\text { for adjudication and registration of natural resources }\end{array}$ \\
\hline
\end{tabular}

Table A3. Structure of the private rights of natural resource assets.

\begin{tabular}{|c|c|c|c|c|c|}
\hline First Level & Second Level & Subject & Object & Rights & Legal Basis \\
\hline \multirow{9}{*}{$\begin{array}{c}1 \\
\text { Ownership }\end{array}$} & $\begin{array}{l}\text { 1.1 Ownership of } \\
\text { state land }\end{array}$ & State & State-owned land & $\begin{array}{l}\text { Rights of possession, use, profit, } \\
\text { and transfer }\end{array}$ & $\begin{array}{c}\text { Constitution, } \\
\text { property law, } \\
\text { land } \\
\text { administration } \\
\text { law }\end{array}$ \\
\hline & $\begin{array}{l}\text { 1.2 Ownership of } \\
\text { collective land }\end{array}$ & $\begin{array}{l}\text { Rural } \\
\text { collective }\end{array}$ & $\begin{array}{l}\text { Collective-owned } \\
\text { land }\end{array}$ & $\begin{array}{l}\text { Rights of possession, use, and } \\
\text { profit. Restricted transfer. } \\
\text { Changed to state ownership } \\
\text { after expropriation }\end{array}$ & $\begin{array}{c}\text { Constitution, } \\
\text { property law, } \\
\text { land } \\
\text { administration } \\
\text { law }\end{array}$ \\
\hline & $\begin{array}{l}1.3 \text { Ownership of } \\
\text { minerals }\end{array}$ & State & Minerals & $\begin{array}{l}\text { Rights of possession, use, profit, } \\
\text { and transfer }\end{array}$ & $\begin{array}{c}\text { Constitution, } \\
\text { property law, } \\
\text { and minerals } \\
\text { law }\end{array}$ \\
\hline & $\begin{array}{l}\text { 1.4 Ownership of } \\
\text { river flow }\end{array}$ & State & River flow & $\begin{array}{l}\text { Rights of possession, use, profit, } \\
\text { and transfer }\end{array}$ & $\begin{array}{c}\text { Constitution, } \\
\text { property law } \\
\text { water law }\end{array}$ \\
\hline & $\begin{array}{l}1.5 \text { Ownership of } \\
\text { wasteland }\end{array}$ & State & Wasteland & $\begin{array}{l}\text { Rights of possession, use, profit, } \\
\text { and transfer }\end{array}$ & $\begin{array}{l}\text { Constitution, } \\
\text { property law }\end{array}$ \\
\hline & $\begin{array}{l}\text { 1.6 Ownership of } \\
\text { forest }\end{array}$ & State & Forest & $\begin{array}{l}\text { Rights of possession, use, profit, } \\
\text { and transfer }\end{array}$ & $\begin{array}{l}\text { Constitution, } \\
\text { property law, } \\
\text { forest law }\end{array}$ \\
\hline & $\begin{array}{l}\text { 1.7 Ownership of } \\
\text { pasture }\end{array}$ & State & Pasture & $\begin{array}{l}\text { Rights of possession, use, profit, } \\
\text { and transfer }\end{array}$ & $\begin{array}{c}\text { Constitution, } \\
\text { property law, } \\
\text { pasture law }\end{array}$ \\
\hline & $\begin{array}{c}1.8 \text { Ownership of } \\
\text { sea }\end{array}$ & State & Sea & $\begin{array}{l}\text { Rights of possession, use, profit, } \\
\text { and transfer }\end{array}$ & $\begin{array}{c}\text { Constitution, } \\
\text { property law, } \\
\text { sea use } \\
\text { administration } \\
\text { law }\end{array}$ \\
\hline & $\begin{array}{c}1.9 \text { Ownership of } \\
\text { beach }\end{array}$ & State & Beach & $\begin{array}{l}\text { Rights of possession, use, profit, } \\
\text { and transfer }\end{array}$ & $\begin{array}{l}\text { Constitution, } \\
\text { property law }\end{array}$ \\
\hline
\end{tabular}


Table A3. Cont.

\begin{tabular}{|c|c|c|c|c|c|}
\hline First Level & Second Level & Subject & Object & Rights & Legal Basis \\
\hline & $\begin{array}{l}1.10 \text { Ownership } \\
\text { of building/house }\end{array}$ & $\begin{array}{l}\text { Lawful } \\
\text { individual } \\
\text { and } \\
\text { organization }\end{array}$ & Building/house & $\begin{array}{l}\text { Houses on state-owned land } \\
\text { involve the right of possession, } \\
\text { use, profit, and transfer. The } \\
\text { scope of transfer of houses on } \\
\text { collective-owned land is } \\
\text { restricted within the collective. }\end{array}$ & $\begin{array}{c}\text { Constitution, } \\
\text { property law, } \\
\text { urban real } \\
\text { estate } \\
\text { administration } \\
\text { law }\end{array}$ \\
\hline & $\begin{array}{l}\text { 1.12 Ownership } \\
\text { of structure }\end{array}$ & $\begin{array}{l}\text { Lawful } \\
\text { individual } \\
\text { and } \\
\text { organization }\end{array}$ & Structure & $\begin{array}{l}\text { Rights of possession, use, profit, } \\
\text { and transfer }\end{array}$ & $\begin{array}{l}\text { Constitution, } \\
\text { property law, } \\
\text { urban real } \\
\text { estate } \\
\text { administration } \\
\text { law }\end{array}$ \\
\hline \multirow[t]{6}{*}{2 Usufruct } & $\begin{array}{l}2.1 \text { Right to use } \\
\text { state-owned } \\
\text { agricultural land }\end{array}$ & $\begin{array}{c}\text { Lawful } \\
\text { individual } \\
\text { and } \\
\text { organization }\end{array}$ & $\begin{array}{l}\text { State-owned } \\
\text { agriculture land }\end{array}$ & $\begin{array}{l}\text { Rights of possession, use, profit, } \\
\text { and transfer }\end{array}$ & $\begin{array}{l}\text { Property law, } \\
\text { land } \\
\text { administration } \\
\text { law }\end{array}$ \\
\hline & $\begin{array}{l}2.2 \text { Right to use } \\
\text { state-owned } \\
\text { construction land }\end{array}$ & $\begin{array}{l}\text { Lawful } \\
\text { individual } \\
\text { and } \\
\text { organization }\end{array}$ & $\begin{array}{c}\text { State-owned } \\
\text { construction land }\end{array}$ & $\begin{array}{l}\text { Rights of possession, use, profit, } \\
\text { and transfer when acquired } \\
\text { with compensation. Rights of } \\
\text { possession and use when } \\
\text { acquired without compensation. } \\
\text { Rights of profit and transfer are } \\
\text { obtained after the transfer fees } \\
\text { have been paid. }\end{array}$ & $\begin{array}{l}\text { Property law, } \\
\text { land } \\
\text { administration } \\
\text { law, urban real } \\
\text { estate } \\
\text { administration } \\
\text { law }\end{array}$ \\
\hline & $\begin{array}{l}2.4 \text { Right to use } \\
\text { sea areas }\end{array}$ & $\begin{array}{l}\text { Lawful } \\
\text { individual } \\
\text { and } \\
\text { organization }\end{array}$ & $\begin{array}{l}\text { State-ownedsea } \\
\text { area }\end{array}$ & $\begin{array}{l}\text { Rights of possession, use, and } \\
\text { profit. Transfer of the property } \\
\text { requires an administrative } \\
\text { license from the sea } \\
\text { administration department. }\end{array}$ & $\begin{array}{l}\text { Property law, } \\
\text { sea use } \\
\text { administration } \\
\text { law }\end{array}$ \\
\hline & $\begin{array}{l}2.5 \text { Right to use } \\
\text { uninhabited } \\
\text { islands }\end{array}$ & $\begin{array}{l}\text { Lawful } \\
\text { individual } \\
\text { and } \\
\text { organization }\end{array}$ & $\begin{array}{l}\text { Uninhabited } \\
\text { island }\end{array}$ & $\begin{array}{l}\text { Rights of possession, use, and } \\
\text { profit. Transfer of the property } \\
\text { requires an administrative } \\
\text { license from the sea } \\
\text { administration department. }\end{array}$ & $\begin{array}{l}\text { Property law, } \\
\text { sea use } \\
\text { administration } \\
\text { law }\end{array}$ \\
\hline & 2.6 Mining right & $\begin{array}{l}\text { Organization } \\
\text { with mining } \\
\text { qualification }\end{array}$ & $\begin{array}{l}\text { Minerals at the } \\
\text { surface, } \\
\text { underground, or } \\
\text { underwater }\end{array}$ & $\begin{array}{l}\text { Rights of possession, use, and } \\
\text { profit. Transfer of the property } \\
\text { requires an administrative } \\
\text { license from the minerals } \\
\text { administration department. }\end{array}$ & $\begin{array}{l}\text { Property law, } \\
\text { minerals law }\end{array}$ \\
\hline & $\begin{array}{l}\text { 2.7 Right to use } \\
\text { forests and } \\
\text { forestlands }\end{array}$ & $\begin{array}{l}\text { Lawful } \\
\text { individual } \\
\text { and } \\
\text { organization }\end{array}$ & $\begin{array}{l}\text { Forest land and } \\
\text { attached trees }\end{array}$ & $\begin{array}{l}\text { Rights of possession, use, and } \\
\text { profit. Transfer of the property } \\
\text { requires an administrative } \\
\text { license from the forest } \\
\text { administration department. }\end{array}$ & $\begin{array}{l}\text { Property law, } \\
\text { forest law }\end{array}$ \\
\hline
\end{tabular}


Table A3. Cont.

\begin{tabular}{|c|c|c|c|c|c|}
\hline First Level & Second Level & Subject & Object & Rights & Legal Basis \\
\hline & $\begin{array}{l}2.11 \text { Right to use } \\
\text { homestead land }\end{array}$ & $\begin{array}{l}\text { Member of } \\
\text { collective }\end{array}$ & Homestead land & $\begin{array}{l}\text { Rights of possession, use, and } \\
\text { profit. The scope of the transfer } \\
\text { is restricted to members of the } \\
\text { collective. }\end{array}$ & $\begin{array}{l}\text { Property law, } \\
\text { land } \\
\text { administration } \\
\text { law }\end{array}$ \\
\hline $\begin{array}{l}3 \text { Security } \\
\text { right }\end{array}$ & 3.1 Mortgage & $\begin{array}{l}\text { Lawful } \\
\text { individual } \\
\text { and } \\
\text { organization }\end{array}$ & Mortgaged land & $\begin{array}{l}\text { Rights of possession, use, and } \\
\text { profit. The mortgage cannot be } \\
\text { transferred independently. }\end{array}$ & $\begin{array}{l}\text { Property law, } \\
\text { security law }\end{array}$ \\
\hline
\end{tabular}

Table A4. Structure of public rights of natural resource assets.

\begin{tabular}{|c|c|c|c|c|}
\hline Planning & Subject & Object & Regulations & Legal Basis \\
\hline $\begin{array}{l}\text { Urban and rural } \\
\text { planning }\end{array}$ & Ditto & $\begin{array}{l}\text { Land parcels and } \\
\text { houses within the } \\
\text { zoning }\end{array}$ & $\begin{array}{l}\text { To create a pleasant living } \\
\text { environment and provide fair } \\
\text { infrastructure services }\end{array}$ & $\begin{array}{l}\text { Urban and rural } \\
\text { planning law }\end{array}$ \\
\hline Sea use planning & Ditto & $\begin{array}{l}\text { Sea and breach } \\
\text { areas within the } \\
\text { zoning }\end{array}$ & $\begin{array}{l}\text { To control the scale and distribution } \\
\text { of sprawl of non-ecological marine } \\
\text { areas and strictly protect sensitive } \\
\text { and fragile areas of marine ecology }\end{array}$ & $\begin{array}{l}\text { Sea use administration } \\
\text { law }\end{array}$ \\
\hline $\begin{array}{l}\text { Territory space } \\
\text { planning }\end{array}$ & Ditto & $\begin{array}{l}\text { Earth surface and } \\
\text { fixtures within } \\
\text { the zoning }\end{array}$ & $\begin{array}{l}\text { To create spatial order and promote } \\
\text { sustainable development }\end{array}$ & $\begin{array}{l}\text { Opinions for the } \\
\text { establishment and } \\
\text { supervision of a territory } \\
\text { space planning system }\end{array}$ \\
\hline
\end{tabular}

\section{References}

1. Cai, Y. Principles of Natural Resources Science; Science Press: Beijing, China, 2000. (In Chinese)

2. Ho, P. Institutions in Transition: Land Ownership, Property Rights, Social Conflicts in China; Oxford University Press: New York, NY, USA, 2005.

3. Yan, W.; Gui, L.; Gui, Q. Resources and Environment and Sustainable Development; Economic Science Press: Beijing, China, 2013. (In Chinese)

4. Williamson, I.; Enemark, S.; Wallace, J.; Rajabifard, A. Land Administration for Sustainable Development; ESRI Press: Redlands, CA, USA, 2010.

5. United Nations Economic Commission for Europe. Land Administration Guidelines: With Special Reference to Countries in Transition; United Nations Publication: New York, NY, USA; Geneva, Switzerland, 1996.

6. Larsson, G. Land Registration and Cadastral Systems: Tools for Land Information and Management; Wiley: New York, NY, USA, 1991.

7. Zevenbergen, J. System of Land Registration: Aspects and Effects; Geodesy Volume 51; Delft University of Techlonogy: Delft, The Netherland, 2002. 
8. Dale, P.F.; McLaughlin, J.D. Land Administration; Oxford University Press: Oxford, UK, 1999.

9. Lemmen, C.; van der Molen, P.; van Oosterom, P.; Ploeger, H.; Quak, W.; Stoter, J.; Zevenbergen, J. A modular standard for the cadastral domain. In Proceedings of the 3rd International Symposium on Digital Earth, Brno, Czech Republic, 21-25 September 2003. Available online: https://webapps.itc.utwente.nl/librarywww/ papers_2003/non_peer_conf/lemmen_modular.pdf (accessed on 13 October 2019).

10. Lemmen, C.; van Oosterom, P.; Bennett, R. The land administration domain model. Land Use Policy 2015, 49, 535-545. [CrossRef]

11. Van Oosterom, P.; Lemmen, C.; Ingvarsson, T.; van der Molen, P.; Ploeger, H.; Quak, W.; Stoter, J.; Zevenbergen, J. The core cadastral domain model. Comput. Environ. Urban Syst. 2006, 30, 627-660. [CrossRef]

12. Lemmen, C. A Domain Model for Land Administration. Ph.D. Thesis, Delft University of Technology, Delft, The Netherlands, 2012. Available online: https://webapps.itc.utwente.nl/librarywww/papers_2012/phd/ lemmen.pdf (accessed on 13 October 2019).

13. Van Oosterom, P.; Lemmen, C. The land administration domain model (LADM): Motivation, standardisation, application and further development. Land Use Policy 2015, 49, 527-534. [CrossRef]

14. ISO. ISO 19152:2012 Geographic Information-Land Administration Domain Model (LADM); ISO: Geneva, Switzerland, 2012.

15. Paulsson, J.; Paasch, J.M. The land administration domain model-A literature survey. Land Use Policy 2015, 49, 546-551. [CrossRef]

16. Athanasiou, K.; Sutherland, M.; Kastrisios, C.; Tsoulos, L.; Griffith-Charles, C.; Davis, D.; Dimopoulou, E. Toward the development of a marine administration system based on international standards. ISPRS Int. J. Geo Inf. 2017, 6, 194. [CrossRef]

17. Flego, V.; Roic, M. Land tenure registration on the marine areas in Croatia. Ocean Coast. Manag. 2018, 166, 72-81. [CrossRef]

18. Zhuo, Y.; Ma, Z.; Lemmen, C. Integration of Land and Housing in China: First Analysis of Legal Requirements for LADM Compliance. In Proceedings of the 5th LADM Workshop, Kuala Lumpur, Malaysia, 24-25 September 2013. Available online: https://www.fig.net/resources/proceedings/2013/2013_ladm/06.pdf (accessed on 13 October 2019).

19. Coruhlu, Y.E.; Yildiz, O. Geographical data model for cultural immovable properties. Surv. Rev. 2018, 50, 487-500. [CrossRef]

20. Gogolou, C.; Dimopoulou, E. Land administration standardization for the integration of cultural heritage in land use policies. Land Use Policy 2015, 49, 617-625. [CrossRef]

21. Radulović, A.; Sladić, D.; Govedarica, M. Towards 3D Cadastre in Serbia: Development of Serbian Cadastral Domain Model. ISPRS Int. J. Geo Inf. 2017, 6, 312. [CrossRef]

22. Döner, F.; Thompson, R.; Stoter, J.; Lemmen, C.; Ploeger, H.; van Oosterom, P.; Zlatanova, S. 4D cadastres: First analysis of legal, organizational, and technical impact-With a case study on utility networks. Land Use Policy 2010, 27, 1068-1081. [CrossRef]

23. OGC. Land and Infrastructure Conceptual Model Standard; Doc. No. 15-111r1; OGC: Wayland, MA, USA, 2016.

24. OGC. OGC InfraGML 1.0: Part 7-LandInfra Land Division-Encoding Standard Doc; No. 16-107R2; OGC: Wayland, MA, USA, 2017.

25. Lemmen, C.; van Oosterom, P.J.M.; Kalantari, M. Towards a new working item proposal for Edition II of LADM. In Proceedings of the 7th Land Administration Domain Model Workshop, Zagreb, Croatia, 12-13 April 2018; p. 24. Available online: http://www.gdmc.nl/publications/2018/21-22_LADM_2018.pdf (accessed on 13 October 2019).

26. Van Oosterom, P.; Kara, A.; Kalogianni, E.; Shnaidman, A.; Indrajit, A.; Alattas, A.; Lemmen, C. Joint ISO/TC 211 and OGC revision of the LADM: Valuation information, spatial planning information, SDG land indicators, refined survey model, links to BIM, support of LA processes, technical encodings, and much more on their way! In Proceedings of the FIG Working Week 2019: Geospatial Information for a Smarter Life and Environmental Resilience, Hanoi, Vietnam, 22-26 April 2019; p. 25. Available online: https://www.fig.net/resources/ proceedings/fig_proceedings/fig2019/papers/ts01i/TS01I_van_oosterom_kara_et_al_10079.pdf (accessed on 13 October 2019).

27. Zhuo, Y.F.; Ma, Z.M.; Lemmen, C.; Bennett, R.M. Application of LADM for the integration of land and housing information in China: The legal dimension. Land Use Policy 2015, 49, 634-648. [CrossRef] 
28. Ying, S.; Guo, R.; Li, L. An uniform real-estate registration model for China. In Proceedings of the 6th International FIG 3D Cadastre Workshop, Delft, The Netherlands, 2-4 October 2018.

29. Yu, C.B.; Li, L.; He, B.; Zhao, Z.G.; Li, X.M. LADM-based modeling of the unified registration of immovable property in China. Land Use Policy 2017, 64, 292-306. [CrossRef]

30. Guo, R.Z.; Li, L.; Ying, S.; Luo, P.; He, B.; Jiang, R.R. Developing a 3D cadastre for the administration of urban land use: A case study of Shenzhen, China. Comput. Environ. Urban Syst. 2013, 40, 46-55. [CrossRef]

31. Cagdas, V.; Stubkjaer, E. Design research for cadastral systems. Comput. Environ. Urban Syst. 2011, 35, 77-87. [CrossRef]

32. Kalantari, M.; Dinsmore, K.; Urban-Karr, J.; Rajabifard, A. A roadmap to adopt the land administration domain model in cadastral information systems. Land Use Policy 2015, 49, 552-564. [CrossRef]

33. Sladić, D.; Radulović, A.; Govedarica, M.; Jovanović, D.; Pržulj, Đ. The use of ontologies in cadastral systems. Comput. Sci. Inf. Syst. 2016, 13, 311. [CrossRef]

34. Kuai, X.; Li, L.; Luo, H.; Hang, S.; Zhang, Z.; Liu, Y. Geospatial information categories mapping in a cross-lingual environment: A case study of "surface water" categories in Chinese and American topographic maps. ISPRS Int. J. Geo Inf. 2016, 5, 90. [CrossRef]

35. Chen, Z.; Song, J.; Yang, Y. An approach to measuring semantic relatedness of geographic terminologies using a thesaurus and lexical database sources. ISPRS Int. J. Geo Inf. 2018, 7, 98. [CrossRef]

36. Henssen, J.L.G. Basic principles of the main cadastral systems in the world. In Proceedings of the One Day Seminar Held during the Annual Meeting of Commission 7, Cadastre and Rural Land Management; The International Federation of Surveyors (FIG): Delft, The Netherlands, 1995.

37. Paasch, J. Legal cadastral domain model: An object-oriented approach. Nord. J. Surv. Real Estate Res. 2005, 2, 117-136.

38. Paasch, J. Classification of Real Property Rights: A Comparative Study of Real Property Rights in Germany, Ireland, the Netherlands and Sweden; KTH Royal Institute of Technology: Stockholm, Sweden, 2011.

39. Paasch, J. Standardization of Real Property Rights and Public Regulations; KTH Royal Institute of Technology: Stockholm, Sweden, 2012. Available online: https://people.utm.my/tlchoon/files/2016/02/Standardization-ofReal-Property-Rights-and-Public-Regulations-Phd-Thesis.pdf (accessed on 13 October 2019).

40. Wong, V. Land policy reform in China: Dealing with forced expropriation and the dual land tenure system. In Centre for Comparative and Public Law Occasional Paper No. 25; Faculty of Law, The University of Hong Kong: Hong Kong, China, 2014. Available online: http://www.law.hku.hk/ccpl/wp-content/uploads/2018/03/ Pub/OP/OP\%20No\%2025\%20Vince\%20Wong.pdf (accessed on 13 October 2019).

41. Alsen, J. An introduction to Chinese property law. Md. J. Int. Law 1996, 20, 3.

42. Fu, H.; Gillespie, J. Resolving Land Disputes in East Asia: Exploring the Limits of Law; Cambridge University Press: Cambridge, UK, 2014.

43. Schmid, C.U.; Hertel, C.; Wicke, H. Real Property Law and Procedure in the European Union: General Report; European University Institute (EUI): Florence, Italy; European Private Law Forum: Würzburg, Germany; Deutsches Notarinstitut (DNotI): Würzburg, Germany, 2005. Available online: https://www.eui.eu/Documents/DepartmentsCentres/Law/ResearchTeaching/ResearchThemes/ EuropeanPrivateLaw/RealPropertyProject/GeneralReport.pdf (accessed on 13 October 2019).

44. Wu, C.; Ye, Y.; Wu, Y.; Yue, W. Territory Space Planning; China Geological Press: Beijing, China, 2019. (In Chinese)

45. Barton, B.; Hernandez, L.K.B.; Lucas, A.R.; Ronne, A. Regulating Energy and Natural Resources; Oxford University Press: Oxford, NY, USA, 2006.

46. McHarg, A.; Barton, B.; Bradbrook, A.; Godden, L. Property and the Law in Energy and Natural Resources; Oxford University Press: Oxford, NY, USA, 2010.

47. Kuhn, T.M. The Structure of Scientific Revolutions, 3rd ed.; University of Chicago Press: Chicago, IL, USA; London, UK, 1996.

48. Enemark, S.; McLaren, R.; van der Molen, P. Land Governance in Support of the Millennium Development Goals; International Federation of Surveyors: Copenhagen, Denmark, 2010. Available online: http://www.fig.net/resources/proceedings/fig_proceedings/fig2010/papers/inv01/inv01_enemark_ vandermolen_et_al_4662.pdf (accessed on 13 October 2019).

49. Lin, Q.W.; Kalantari, M.; Rajabifard, A.; Li, J.F. A path dependence perspective on the Chinese cadastral system. Land Use Policy 2015, 45, 8-17. [CrossRef] 
50. Cagdas, V.; Kara, A.; Oosterom, P.; Lemmen, C.; Isikdag, U.; Kathmann, R.; Stubkjær, E. An initial design of ISO 19152:2012 LADM based valuation and taxation data model. ISPRS J. Photogramm. Remote Sens. 2016, 4, 145-154. [CrossRef]

51. Zevenbergen, J.; Frank, A.; Stubkjaer, E. Real Property Transactions: Procedures, Transaction Costs and Models; IOS Press: Amsterdam, The Netherland, 2007. 